\title{
Business model innovation drivers as antecedents of performance
}

\author{
Salvatore Ammirato, Roberto Linzalone and Alberto Michele Felicetti
}

\author{
Salvatore Ammirato, \\ Roberto Linzalone and \\ Alberto Michele Felicetti are \\ all based at the Department \\ of Mechanical, Energy and \\ Management Engineering, \\ University of Calabria, \\ Rende, Italy.
}

Received 29 January 2021 Revised 21 June 2021 Accepted 25 August 2021

(C) Salvatore Ammirato, Roberto Linzalone and Alberto Michele Felicetti. Published by Emerald Publishing Limited. This article is published under the Creative Commons Attribution (CC BY 4.0) licence. Anyone may reproduce, distribute, translate and create derivative works of this article (for both commercial and non-commercial purposes), subject to full attribution to the original publication and authors. The full terms of this licence may be seen at http://creativecommons.org/licences/by/4.0/ legalcode

\begin{abstract}
Purpose - The innovation of business model (BM) is a strategic process for many firms, from which depends competitiveness and sustainability. Despite its theoretical relevance in management sciences, research on business model innovation is in its infancy and lacks of research consistency and theoretical connections to the theme of "performance". With the aim to contribute in bridging this gap, this paper aims to identify and analyse drivers of business model innovation performance.

Design/methodology/approach - This research is based on an integrative literature review methodology.

Findings - BMl performance drivers are conditions related to various dimensions (i.e. processes, resources, market, BM structure, etc). that, when fulfilled, allow the BMI to have higher performance. BMI performance drivers are antecedents of BMI performance, and their identification is of both theoretical and practical value. The authors find and report a set of $35 \mathrm{BMI}$ performance drivers.

Originality/value - The value of this research is both theoretical and practical. From a theoretical point of view, the identified "Business Model Innovation performance drivers" define and identify a variable of BMI performance, from a practical perspective, and they provide a comprehensive set of key conditions whose attainment should be planned, pursued and monitored by managers.
\end{abstract}

Keywords Performance, Driver, Business model innovation, Digital enterprise, Performance driver, Literature review

Paper type Research paper

\section{Introduction}

In the past couple of decades, start-ups and established firms have innovated their business models to exploit digital technologies at full steam. Namely, existing enterprises have shifted from physical to digital processes and products, while nascent firms have started directly with digital-based businesses (Ammirato et al., 2020; Wirtz, 2019; Zott and Amit, 2017). Both leading actors of the so-called "digital revolution" (Kraus et al., 2019b; Nambisan, 2017; Rachinger et al., 2019) distinguished for the capacity to design and change (i.e. to innovate) the Business Models, rather than the technology itself. They proved that Business Model Innovation (BMI) can profit higher then product and process innovation, making BMI a strategic process to boost firm's competitiveness and sustainability (Hagiu and Wright, 2015; Kraus et al., 2019a; Wirtz, 2019). Two companies with the same resources, assets and digital technology, can have completely different business performance in reason of different BMs (Hagiu and Wright, 2015).

Business model innovation (BMI) is a theoretically relevant topic in today's management literature. Its connection with firm's business performance, and then its effects on company's competitiveness is agreed and highlighted by many prominent scholars (Chesbrough, 2010; Osterwalder et al., 2005; Spieth et al., 2014; Wirtz, 2019).

However, if foundational studies on BM addressed conceptualization and definition (Chesbrough and Rosenbloom, 2002; Teece, 2010), categorizations and classifications 
(Demil and Lecocq, 2010; Kraus et al., 2019a), while later studies embraced empirical and context-specific research questions (Bocken et al., 2018; Hartmann et al., 2016; Wirtz and Daiser, 2018), very little is investigated, up to now, about the performances of BMI (Nielsen et al., 2014, 2018). If, on the one side, the link between BMl performance and firm's performance is detected and argued (Chesbrough, 2010; Geissdoerfer et al., 2018; Wirtz, 2019; Zott and Amit, 2007), on the other side, there is a noticeable lack of research on what influences BMI performance (i.e. antecedents of BMI performance).

One determinant of BMI performance are the drivers. They are the conditions, regarding various firm's objects (i.e. processes, resources, market, Business model, others), that if fulfilled allow the firm to have higher performance in BMI. BMI performance drivers are hypothesized to be antecedents of BMI performance.

By crossing the concept of business driver with that of BMI performance, we argue that $B M I$ performance driver (BMIpd) is a variable of BMl performance; hence, we reviewed literature to find if and how BMlpds influence BMl performance.

This research carried out a unified and comprehensive view of both the drivers and the performance effect connected, in BMI.

To bridge the literature gap about antecedents of BMI performance and contribute to the open problem of a performance management theory of BMI (Nielsen et al., 2018; Wirtz, 2019), our research addresses the question: which are BMIpd influencing the performance of $B M I$ ?

To answer this question we carried out an Integrative Literature Review (Bryman and Bell, 2011; Snyder, 2019; Torraco, 2005), that lead to identify a list of 14 key sources able to answer the question.

Results of our research let us to reach three aims: first, review and group together existing research on BMI under the theoretical perspective of performance; second, analyse the relation between BMIpd and BMI performance; and, third, provide managerial targets and implications about the drivers of BMI performance.

The remainder of the paper is as follows: Section 2 will review the concept of business model innovation and review the theoretical underpinnings of the concept BMl performance driver. Section 3 will introduce and explain the research methodology, while Section 4 will present the findings and Section 5 will discuss them. Finally, Section 6 will conclude the paper by summarizing main issues, results and research directions for future advancements.

\section{Theoretical background}

\subsection{Business model innovation}

The Business Model (BM) is a conceptual framework that describes the core logic underpinning a business (Afuah and Tucci, 2003; Massa et al., 2017; Osterwalder et al., 2005; Shafer et al., 2005; Teece, 2010; Wirtz, 2019); it represents the architecture of the business resulting from the combination of business core-components with inherent connections (Dubosson et al., 2002; Osterwalder et al., 2005; Timmers, 1998).

Overall, the BM is a conceptual tool that identifies and makes explicit, perhaps by the mean of diagrammatic tools, the key components of a business (i.e. revenues, costs, providers, channels, etc.), and the interactions among these components (transactions, deliveries, partnerships, etc.), into a unique and comprehensive framework.

Among its many benefits, the BM is particularly able to show the logic a business employs to exploit technology and make profits, representing a blueprint of how a network of organizations cooperates in creating and capturing value from technological innovation (Chesbrough and Rosenbloom, 2002; Wirtz, 2019). 
In this way, the BM is a strategic and powerful model to explicit, with a mix of narrative and numbers (Magretta, 2002), how an existing business works, how a new business model is expected to perform, why a certain business is successful/unsuccessful, how to best exploit from digital.

To stay competitive and sustainable along the time firms have to innovate their business model and manage it according to performance. The BM innovation process affects the competitiveness of an enterprise (Afuah and Tucci, 2003), and its sustainability along the time.

$\mathrm{BMI}$ is the process of either the creation of a new business model, or the modification (involving at least one element) of an existing business model (Abdelkafi et al., 2013; Amit and Zott, 2012; Demil and Lecocq, 2010; IBM Institute for Business Value, 2008; Wirtz, 2019) (Bucherer and Uckelmann, 2011; Zott and Amit, 2010). BMI aims to create and capture value in a novel way (Amit and Zott, 2001; Demil and Lecocq, 2010; Frankenberger et al., 2013; Teece, 2010) and allow to meet unsatisfied, new or hidden customer needs (Osterwalder and Pigneur, 2010).

Four business model innovation types can be identified: start up, business model transformation, business model diversification and business model acquisition (Geissdoerfer et al., 2018). Startup is when a firm has no current business model, and new one is created. Transformation is when there is a current business model that is changed into another business model. Diversification is when a current business model stays in place, and an additional business model is created. Acquisition is when an additional business model is identified, acquired and integrated.

In any type BMI can be approached both as a process and as a project. While the project perspective on $\mathrm{BMI}$ is lacking of literature contributions, the one of process has a certain consistency.

BMI, according to the 4-I framework, is a four stages process (Frankenberger et al., 2013): initiation, ideation, integration and implementation. Initiation is about discovering the need for innovation, which starts with an initial event, idea or decision. Ideation is the generation of innovative ideas or alternative solutions. Integration is the selection of the most promising alternative and the inherent elaboration to produce some tangible product, process or service. Finally, integration brings the idea in the broader context by bringing the new Business Model working on the market.

BMI has a particular relevance for DEs, as it support and drives the improvement of organizational performances (Chesbrough, 2010; Osterwalder et al., 2005; Spieth et al., 2014). The centrality of BMI in the creation and keeping of competitive advantages is recognized both from scholars (Chesbrough and Rosenbloom, 2002; Teece, 2010) and practitioners. In particular, entrepreneurs and managers consider BMI more important than product or service innovation (BCG, 2008) as a mean to achieve competitive advantage. Despite the theoretical of $\mathrm{BMI}$ performance, extant literature has practically ignored it (Haggège et al., 2017; Nielsen et al., 2018; Wirtz, 2019) and a desired theory of BMI performance management is far to come (Haggège et al., 2017; Nielsen et al., 2018).

\subsection{Business model innovation performance drivers}

To shed light on the theoretically relevant, despite shaded, issue of BMI performance, we review the main concepts related.

If on one hand BMI performance is positively correlated with firm's performance (Afuah and Tucci, 2003; Geissdoerfer et al., 2017; Latifi and Bouwman, 2018), on the other hand, it is not investigated what influences BMl performance. 
One influential factor of BMI performance are the drivers. BMI has higher performance if specific conditions (i.e. drivers) are fulfilled (Chesbrough, 2010; Latifi and Bouwman, 2018). (Christensen et al., 2016) argue that $60 \%$ of BMl efforts do not deliver the expected improved performance. This, reasonably induce to think that there is a need to explore what are the antecedents of BMI performance, that is cause of higher performance.

The term "driver" in business management literature is generally referred to any important factor of a business. Despite an abundancy of researches aimed at detecting drivers, it is hard to find a clear and agreed definition of business driver.

In Management, a driver is generally meant as a condition, regarding any aspect of a firm, that is vital for the continued success and growth of the business (Techopedia, 2014). A driver determine or cause an increase in value or in performance of a business or a process (Lozano, 2015; Study.com, 2017). Therefore, the driver is a key factor to compare oneself position, both qualitative and/or quantitative, respect to a desired expected value which is linked causally with a higher performance; a driver is then theoretically relevant for processes, being an antecedent of higher performance.

Drivers can be identified for a given business entity like process, product, firm, industry, even global business. The drivers, with particular attention to BMl, have been investigated and classified in: internal and external (Lozano, 2015; Techopedia, 2014), macro and micro (Hayes, 2020; Velamuri et al., 2013), organizational and individual (Rauter et al., 2017), qualitative and quantitative (Rauter et al., 2017), tangible and intangible (soft) (Pucihar et al., 2019), static and dynamic (Haggège et al., 2017), intentional and unintentional (Demil and Lecocq, 2010).

The concept of Drivers of BMI has been addressed in some previous studies, and various context and industries. Velamuri et al. (2013) analysed BMl drivers in the manufacturing industry, Rauter et al. (2017) investigated the drivers for developing business models for sustainability, Pucihar et al. (2019) detected BMI drivers in SMEs. Nonetheless, several studies addressed the question of BMI drivers in Digital Enterprises (Demil and Lecocq, 2010; Zott et al., 2011; Lambert and Davidson, 2013). However, it is not previously focused with regard to BMI performance.

However, the concept is not explored with regard to BMI process, where BMlpds are a set of conditions a company should fulfill to increase the performance of BMI.

BMIpd are theoretically and practically relevant for BMI performance, as they translate into specific objectives, targets and purposeful initiatives (Bersin, 2013) for both scholars and entrepreneurs.

As drivers change with business circumstances like changing markets, and changing technology, also the key drivers can change with the evolutionary stage of a business, for example; a startup's drivers are different then an incumbent (Teece, 2010), thus making digital entrepreneurship a context of emergence and observation of BMI drivers.

Digital technologies (i.e. Internet of Things, artificial intelligence, mobile technologies, social media, business analytics, Big data, advanced manufacturing, 3D printing, cloud and cyber-solutions, MOOCs) (Fisher and Reuber, 2011; Rippa and Secundo, 2018) offer huge business opportunities for those firms that will be able to outperform competitors in BMI (Amit and Zott, 2001; Rippa and Secundo, 2018; Spieth et al., 2014; Teece, 2010; Zaheer et al., 2019).

BMI performance is indeed positively correlated with firms' competitiveness (Geissdoerfer et al., 2018; Johnson et al., 2008; Wirtz, 2019). Hence, BMI performance is a theoretical pivot point for Business Model literature.

Despite more and more enterprises deal with digital technologies, such as incumbent (Kim and Min, 2015) and start-up companies (Hartmann et al., 2016), to engage with BMI higher performance, $B M I$ performance is a shaded, almost unexplored issue of research. 
Recently, BMI scholars have called for causal analyses of antecedences and effects of BMI (Zott et al., 2011; Spieth et al., 2014; Clauss, 2016). With the exception of some qualitative studies, there is little empirical research examining factors which influence the success of BMI in firms (Spieth and Schneider, 2016).

With the aim to contribute to bridge this gap, this paper identifies and analyses the drivers of BMI performance. BMI performance drivers are the conditions, regarding various dimensions (i.e. processes, resources, market, BM structure, etc.), that if fulfilled allow to the BMI to have higher performance. BMI performance drivers are antecedents of $B M I$ performance, and their identification is of both theoretical and practical value.

\section{Research methods}

Given the lacking of former studies and literature, this research has explorative nature. Its aim is not to make the state-of-the-art of existing body of literature, rather than to form a preliminary theoretical hypothesis. Following this assumption the authors employed an Integrative (or critical) literature review (Bryman and Bell, 2011; Snyder, 2019; Torraco, 2005). The integrative literature review, indeed, result in the advancement of new knowledge on theoretical issues, rather than in a detailed and systematic review (Snyder, 2019). To face such emerging topics, the integrative literature review is particularly suited (Bryman and Bell, 2011; Snyder, 2019)

The research was carried out to answer the question: which are business model innovation performance drivers?

Following the steps of an integrative literature review (Snyder, 2019; Torraco, 2005) the authors developed the research through the phases: design, conduct, analysis, structuring and writing the review.

\subsection{Design}

The authors pondered the research value of the study, the audience and the potential impact, to motivate the need of the research (Snyder, 2019; Torraco, 2005). The motivations found by the authors were:

- the research question would move ahead of the definitory stage of BMI performance;

- scholars have recently addressed the need of bridging the gap between the academia and the practice with regard to BMI, to both support practitioners and policy makers, while contextually enlarge and advance empirical research (Giones and Brem, 2017; Nielsen et al., 2018);

- providing novel theoretical and empirical findings to carry out a "4th stage" of research on BMI, the performative stage (Nielsen et al., 2018); and

- the research question is able to identify and disclose one antecedent of BMI performance (Nielsen et al., 2018).

Following these motivations the investigation of BMlpd was assessed of high interest and impact, that is able to provide insights for a desired theory of Performance management of BMI (Nielsen et al., 2018)

About the audience of this study, it was mainly identified in management scholars, digital entrepreneurs, policymakers.

The authors then outlined the research design according to a three steps procedure: appointment of the Web-based scholarly search engine, design of the searching string to input, definition of the selection criteria of the sources. 
Considered that Integrative literature reviews are free of protocols and are suited to investigate emerging topics (Snyder, 2019; Torraco, 2005), the authors embraced a creative collection of data, and avoid a structured protocols, as the purpose is not to cover all articles ever published on the topic but rather to combine perspectives and insights from different fields, research traditions, type of sources, having as a primary objective the coherence of the forwarded theory (Snyder, 2019).

Despite this methodology imposes no specific "guidelines", the research process must be transparent and traceable. To this aim, the authors took notes and details during the research development, about the methodological decisions, to report these choices and make the research replicable and verifiable.

\subsection{Conduct}

To conduct the research a scholarly relevant internet search engine was used: Google Scholar (https://scholar.google.com/). It was chosen after assessment of the main scholarly suitable, internet-based, literature databases: SCOPUS, WEB OF SCIENCE, EBSCO and Google Scholar. The authors assessed Google Scholar as the more inclusive, so to comply with the exploratory nature of the research and of the methodological approach required.

To this aim, after scrutiny of the functions and the envisaged restrictions of the databases' filters, Google Scholar was selected.

Following, the search parameters were designed. No restriction was applied to the type of source, while a restriction was applied to the language (English). No time boundary restriction regarding the dating of the sources was set.

About the keywords, the authors had a brainstorming session to identify the keywords to query the search engine. The keywords were chosen as: "business model innovation", "driver*"; a further list of possible synonyms of "driver" was carried out: "guideline", "suggestion", "orientation", "direction".

The search string entered in the search engine was then the following:

(business model innovation)

AND

(driver") OR (driving) OR (guideline) OR (suggestion) OR (orientation)

The query of the Google scholar data base was administered on November 23rd, 2020. The search returned a list of sources. Full articles were retrieved and reviewed. screened one by one and included in the sample according to fulfilment of the research question. The researchers analysed each single record, by reviewing the abstract, to detect coherent sources and exclude the others. Not relevant sources were discarded, while the relevant ones were included into a list $L$. The exclusion criteria were the consistency with the research question, and coverage of the topic (Table 1).

\subsection{Analysis}

The collected sources were newly reviewed by the authors. For each paper, relevant findings for the research question were analysed, extracted and reported in a comprehensive table to display, compare, combine the findings of the reviewed sources.

\subsection{Structuring and writing}

The structure of the paper is designed to highlight the methods and the results. The first one to make the research transparent and traceable, the second to increase scientific value. No specific standard of reporting was implied. 
Table 1 List L of sampled sources

\begin{tabular}{|c|c|c|}
\hline Title & Author/Year & Journal/Proceeding \\
\hline $\begin{array}{l}\text { 1. Business model performance: five key } \\
\text { drivers }\end{array}$ & $\begin{array}{l}\text { Haggège, M., } \\
\text { Gauthier, C., Rüling, } \\
\text { C.-C., } 2017\end{array}$ & Journal of Business Strategy \\
\hline $\begin{array}{l}\text { 2. Business model innovation performance: } \\
\text { when does adding a new business model } \\
\text { benefit an incumbent? }\end{array}$ & $\begin{array}{l}\text { Kim, S.K. and Min, S, } \\
2015\end{array}$ & Strategic Entrepreneurship Journal \\
\hline 3. Business Model Innovation and Firm & Latifi, M.-A. and & 31th Bled EConference Digital \\
\hline $\begin{array}{l}\text { Performance: The Role of Mediation and } \\
\text { Moderation Factors' }\end{array}$ & Bouwman, H, 2018 & $\begin{array}{l}\text { Transformation-Meeting the } \\
\text { Challenges }\end{array}$ \\
\hline $\begin{array}{l}\text { 4. Measuring business model innovation: } \\
\text { conceptualization, scale development, and } \\
\text { proof of performance }\end{array}$ & Clauss, T, 2016 & RandD Management \\
\hline $\begin{array}{l}\text { 5. Creating Value through Business Model } \\
\text { Innovation }\end{array}$ & Zott and Amit, 2010 & Harvard Business Review \\
\hline $\begin{array}{l}\text { 6. Business Model Innovation: How to Create } \\
\text { Value in a Digital World }\end{array}$ & Zott and Amit, 2017 & Business Model Innovation \\
\hline $\begin{array}{l}\text { 7. Drivers and Outcomes of Business Model } \\
\text { Innovation-Micro, Small and Medium-Sized } \\
\text { Enterprises Perspective }\end{array}$ & Pucihar et al., (2019) & Sustainability \\
\hline $\begin{array}{l}\text { 8. Going one's own way: drivers in developing } \\
\text { business models for sustainability }\end{array}$ & Rauter et al., (2017) & Journal of Cleaner Production \\
\hline $\begin{array}{l}\text { 9. Product Service Systems as a driver for } \\
\text { Business Model Innovation: lessons learned } \\
\text { from the Manufacturing industry }\end{array}$ & Velamuri et al., (2013) & $\begin{array}{l}\text { International Journal of Innovation } \\
\text { Management }\end{array}$ \\
\hline 10. How to Design a Winning Business Model & $\begin{array}{l}\text { Casadesus-Masanell } \\
\text { and Ricart, (2011) }\end{array}$ & Harvard Business Review \\
\hline $\begin{array}{l}\text { 11. Business Models, Business strategy and } \\
\text { Innovation }\end{array}$ & Teece, $(2010)$ & Long Range Planning \\
\hline $\begin{array}{l}\text { 12. Business model evolution: in search of } \\
\text { dynamic consistency }\end{array}$ & $\begin{array}{l}\text { Demil and Lecocq, } \\
\text { (2010) }\end{array}$ & Long Range Planning \\
\hline $\begin{array}{l}\text { 13. The Business Model: Recent } \\
\text { Developments and Future Research }\end{array}$ & Zott et al., (2011) & Journal of Management \\
\hline $\begin{array}{l}\text { 14. Applications of the business model in } \\
\text { studies of enterprise success, innovation and } \\
\text { classification: An analysis of empirical } \\
\text { research from } 1996 \text { to } 2010\end{array}$ & $\begin{array}{l}\text { Lambert and } \\
\text { Davidson, (2013) }\end{array}$ & European Management Journal \\
\hline
\end{tabular}

\section{Findings}

BMI driver is a topic investigated in literature, but not analysed in the perspective of performance. Zott and Amit (2010) propose a framework of BMI drivers, the NICE Framework. Four drivers should guide the innovation of a business model: novelty, lock-in, complementarities, and efficiency. Novelty addresses the adoption of innovative elements; Lock-in addresses the creation of lock-in effects; Complementarities addresses the bundling of activities with the goal of generating added value; Efficiency address the reorganization of the activities to reduce transaction costs.

Casadesus-Masanell and Ricart (2011) discussing about the BMI effectiveness criteria, push forward 3 drivers: alignment, self-reinforcement, robustness. Alignment of the new BM to company's goal is fundamental to avoid exemplary failures in BMI, like the one of Xerox PARC (Casadesus-Masanell and Ricart, 2011). BMI should be carefully aligned to company's goals, rather than to technological exploitation goals.

Self-reinforcement is the driver by which the choices subtended by, and operated in, BMI should complement one another. There must be internal consistency of the innovations, as shown by the BMI of low-cost airlines (Casadesus-Masanell and Ricart, 2011). They offered 
a sensational reduction in price, duly complemented by: increase in the number of seats per aircraft, suppression of on-board services (meals, beverages, ancillaries). These innovations perfectly self-reinforced and resulted into an outperforming new BM.

Robustness is the driver that guarantee a BMl for longevity. A performing BM preserves its effectiveness over time, by fending off four threats: imitation, holdup, slack, substitution. Since the period of effectiveness is gradually shorter, robustness becomes a critical factor.

Casadesus-Masanell and Ricart (2011) also found market drivers for a BMI. They rise for the observation the interactions of the new BM with competitors' established BMs. In this perspective four drivers of BMI are found: creation of virtuous cycles in the market, reinforcement of virtuous cycles in the market, undermine rivals' BMs, turn competitors' strengths into weaknesses.

Haggège et al. (2017) identify five key performance drivers of BMI. They also highlight the interdependence of drivers and argue that specific combinations of drivers matter at different moments in an entrepreneurial firm's life cycle. Therefore, by combining insights from the static and the dynamic view of BMI performance, they propose five key drivers of $\mathrm{BMI}$, supported by a broad range of performance mechanisms. Assuming that BMI performance depends on the business model configuration choices, three drivers arise: rethinking customer engagement, reconfiguring external linkages and optimizing internal processes. Considering the dynamic view, they assume that business model configurations must evolve to match changing conditions. This requires to BMI a high degree of firm-level strategic awareness and reconfiguration capacity; they emanate two drivers: cultivating strategic awareness and developing configuration capacity.

Kim and Min (2015), by observing that some incumbent firms perform better after adding new business models to their existing ones and some other fails in doing the same, derive driving suggestions, in essence drivers, to succeed with multi-BMI. They collect and forward ahead the following drivers:

- Johnson et al. (2008) that highlight to start a new BM with: a customer value proposition, construct a profit formula that allows value delivery to company, compare new models to current ones to determine whether it can be impended in the organization.

- Sosna et al. (2010) that argue that a key driver for BMI is learning from trial-and-error.

- Desyllas and Sako (2013), in the case of incumbent pay-as-a-service car company, formal intellectual property rights are key driver in the initial stage of BMI introduction, as defensive strategy, while specialized complementary assets and reconfiguration of them are needed to gain long-term sustainability.

Clauss (2016) claims the lack of a validated measurement scale for measuring business model innovation. On this basis, he develops a validated scale for business model innovation, made up of three dimensions: Value creation innovation, new proposition innovation, Value capture innovation. Clauss (2016) addresses it as a driver for effective $\mathrm{BMI}$. Each dimension has its proper measures. For Value creation innovation they are: new capabilities, new technology/equipment, new partnership, new processes; for new proposition innovation, they are new offerings, new customer and markets, new channels, new customer relationship; finally for value capture innovation, they are: new revenue models and value cost structures (Table 2).

Lambert and Davidson (2013) focused on the firm's ability in BMI and proposed as drivers of BMI the following: the new BM is well aligned both internally and externally, the design of the new BM and the monitor of its continuous effectiveness, is based on sophisticated analytics, the new BM is adaptable.

Demil and Lecocq (2010), by arguing that a successful BMI is a continuous process that involves an initial experiment followed by continuous reassessment and modification to suit 


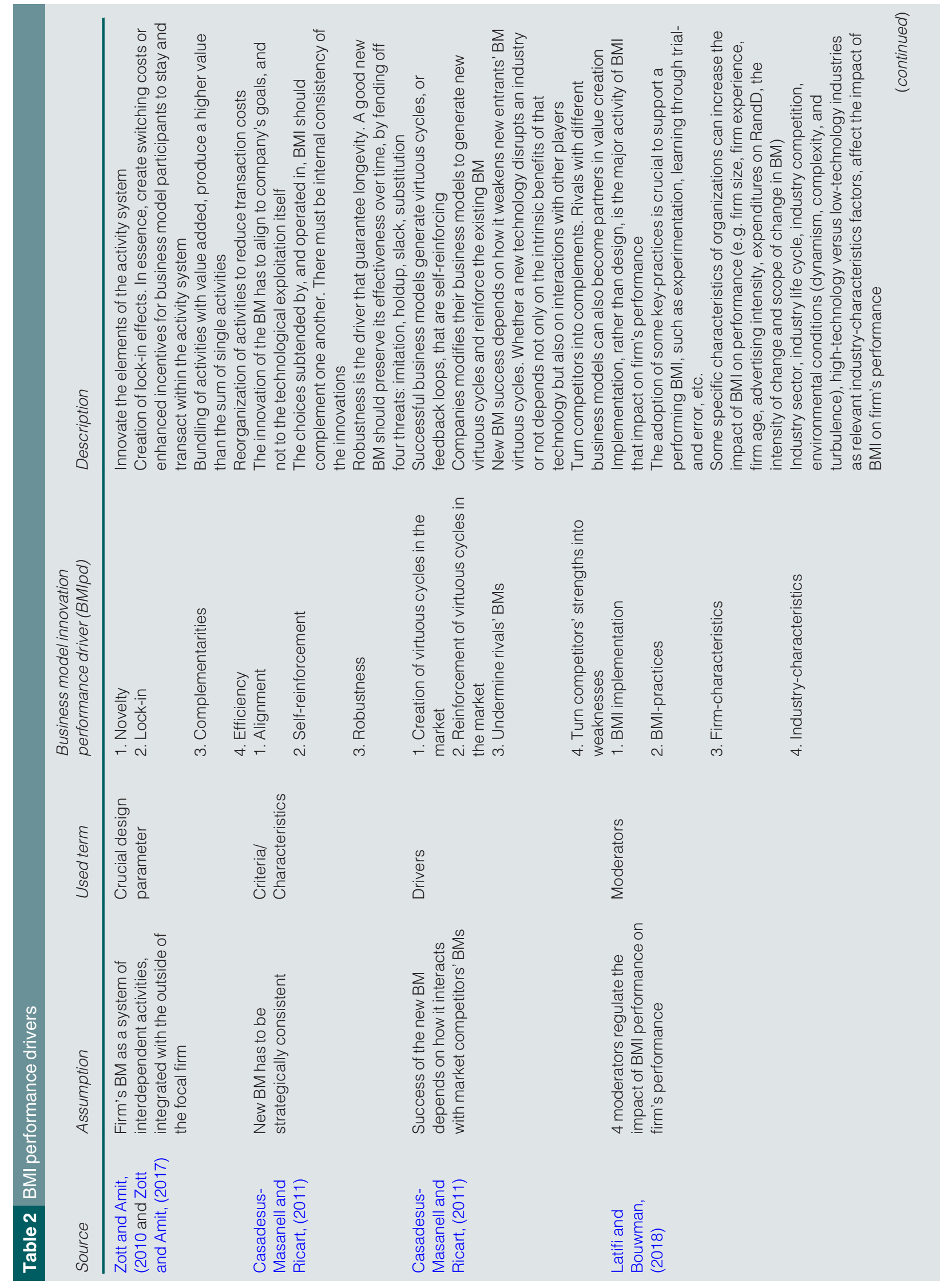




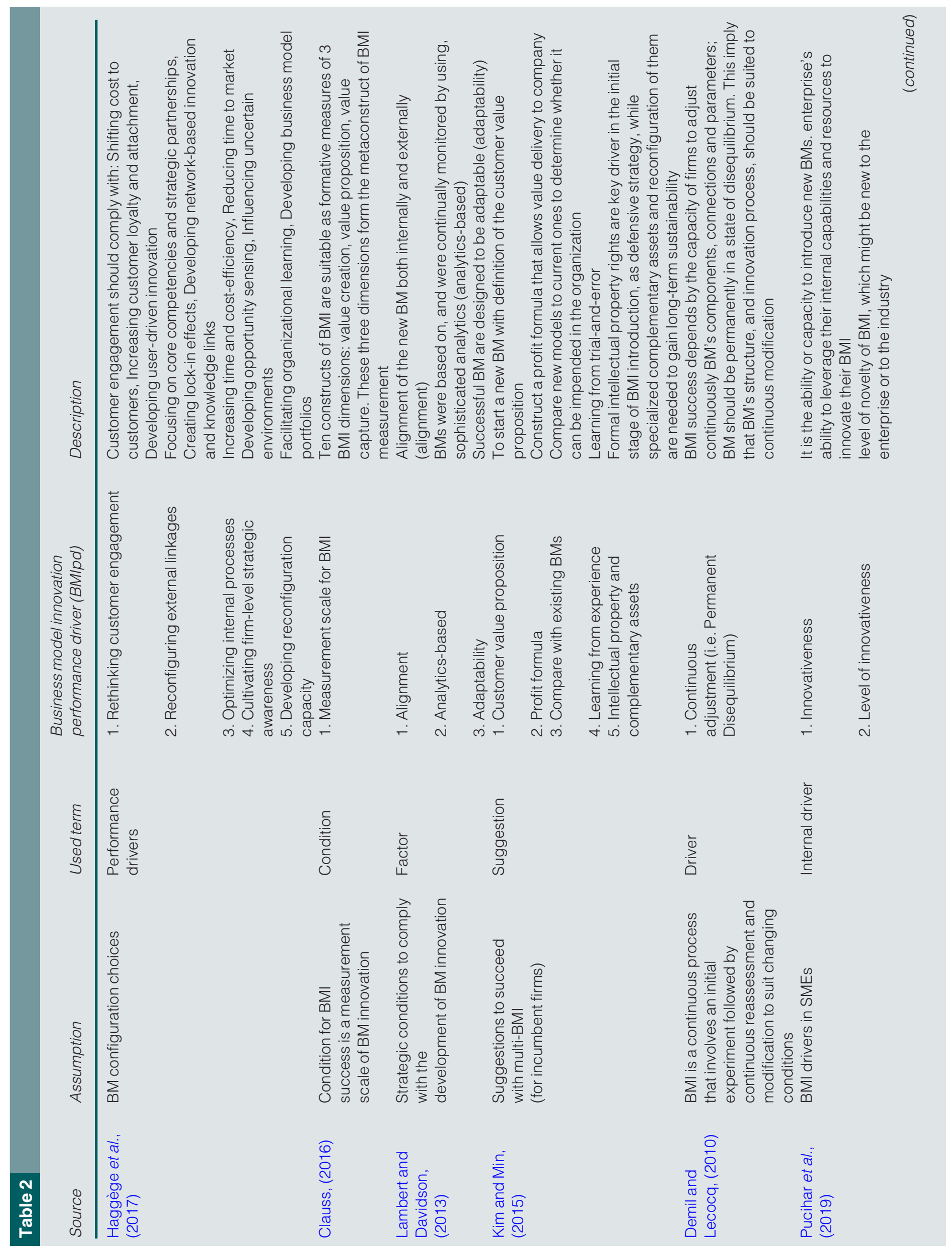




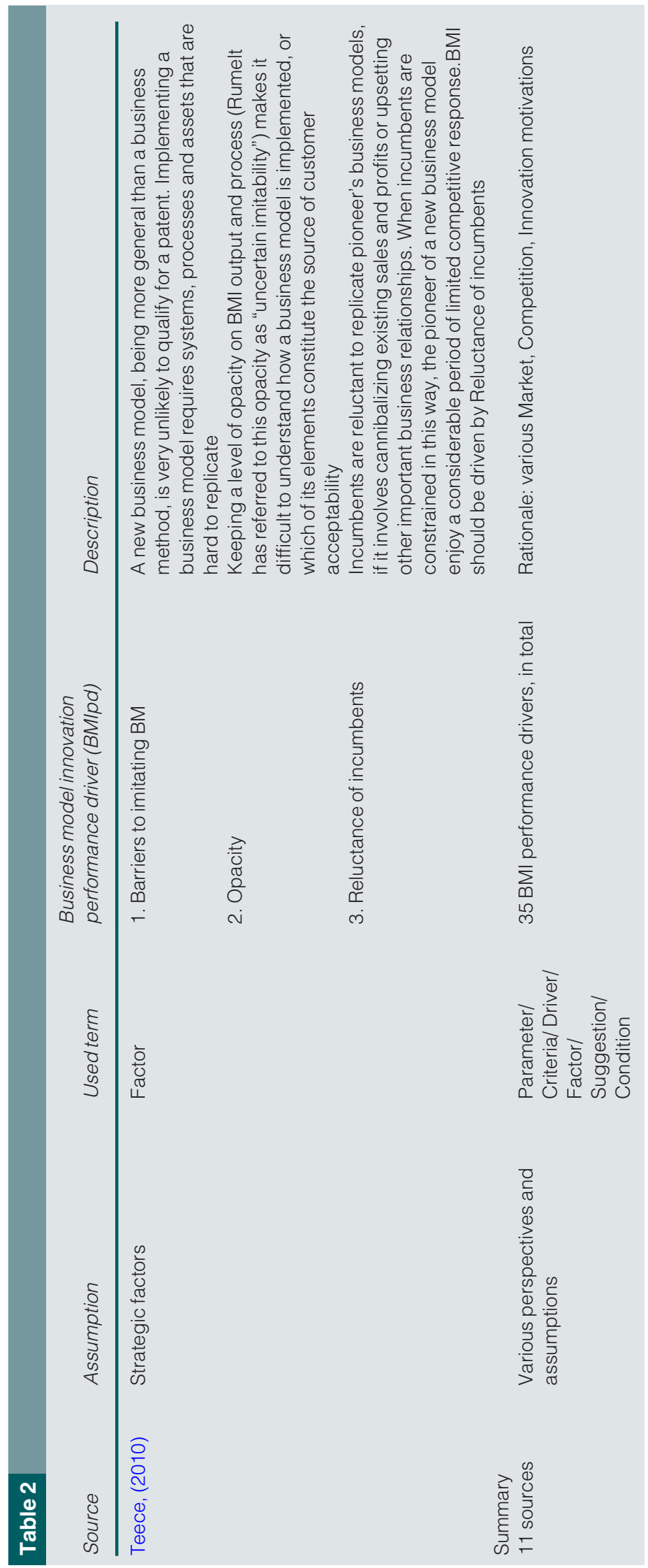


changing conditions, highlighted the tension toward continuous changes (i.e. adjustments) as a driver of BMI; they argued that BMI should be permanently in a state of disequilibrium, and the fulfillment of this condition brings higher performance.

\section{Discussion}

A first point of discussion is on the concept of Driver. Even meaning the same concept, many synonyms are used by scholars for the concept of BMlpd. Casadesus-Masanell and Ricart (2011) use the term criteria for effective development of a BM, Zott and Amit (2010) employ the term crucial parameters of BMI, Haggège et al. (2017) use the terms key drivers of BM development; they all significate the same thing. Despite the concept of BMlpd is wide and can be many things (i.e. conditions, resources, processes) the use of different terms for the same concept, does not allow an effective and efficient research. Search, selection and combination of literature sources is harder, is time-consuming, and theory building slow.

Researches on BM should review results also in terms of BMI Drivers to accumulate knowledge. Besides, terms, means, similarity and differences, interrelations and overlaps of the of "BMI driver" concept should be solved in further research. A common base of understanding and communication, contribute to solve the BM's "striking lack of cumulative theorizing" (Foss and Saebi, 2018) (p. 9). Unifying existing literature is a preliminary step to lay down foundations for the $4^{\text {th }}$, prospective stage of BM theory development: the performance age of BMs (Nielsen et al., 2018).

A second point of discussion is about the evidence of BMlpd as an antecedent of BMI performance. The review of BMlpd induces the emergence of a framework where BMIpd influence the performance of BMI at five levels (i.e. metrics of BMI performance): process, project, business model, business model portfolio, BMI project portfolio (Figure 1).

This framework appears as useful to be harbinger of insights and practical guidance for managers. Accordingly, BMlpds can be grouped along these dimensions to have a complete picture of all the drivers. This results provide a ground for reflections on "Performance management" of BMl (Lambert and Davidson, 2013; Latifi and Bouwman, 2018; Nielsen et al., 2018). BMlpds should be a starting input of the Performance

\section{Figure 1 An emerging framework of BMl drivers}

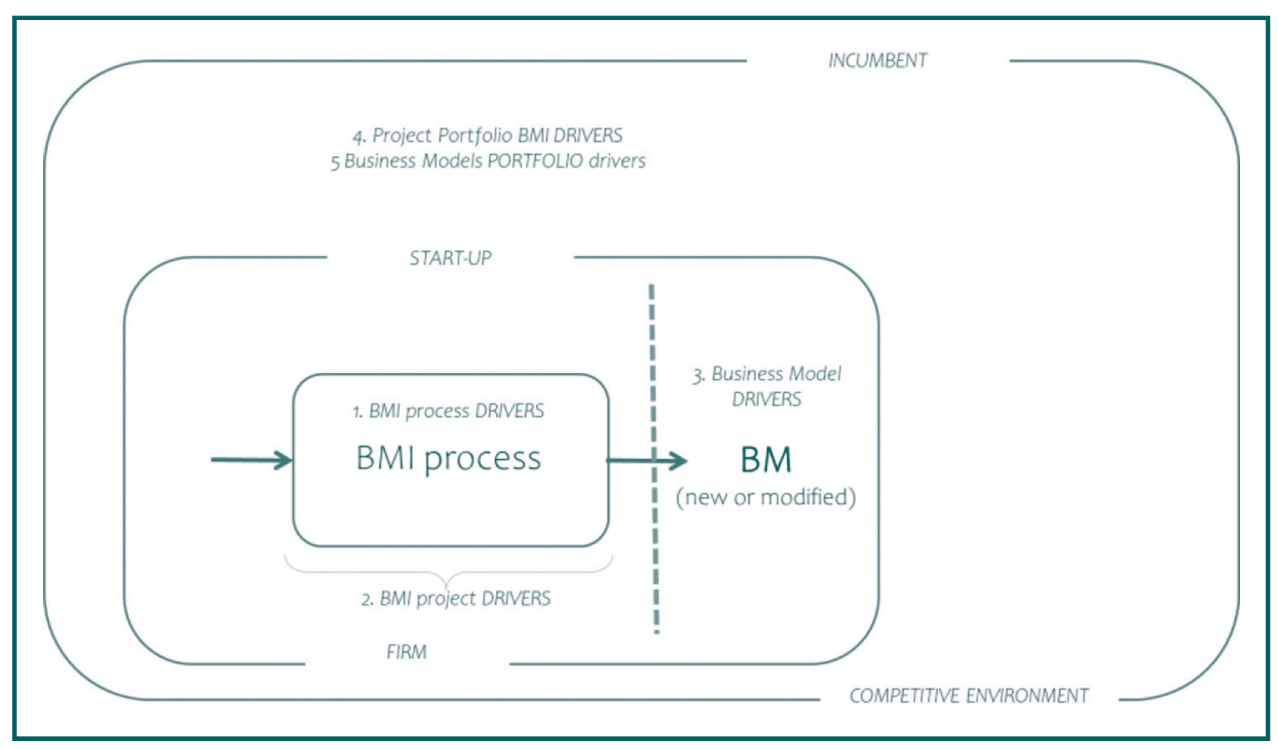




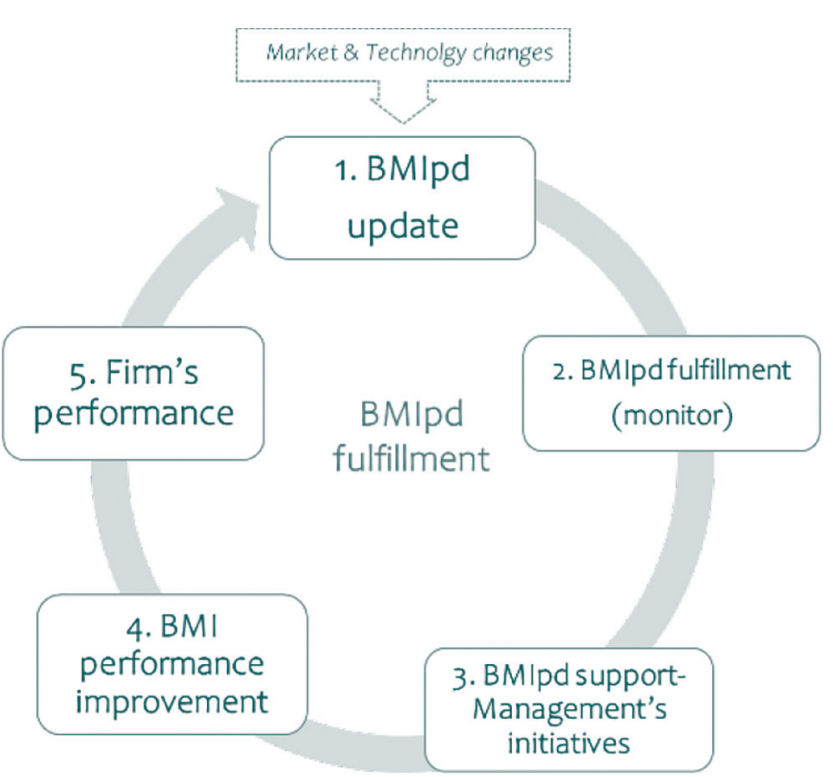

Management system, representing the "winning" factors of any BMI. Performance Management should conform the definition of measures, indicators and information to reflect the achievement, or the keeping, of these factors.

A fourth point of discussion is about the implications that rise for Managers and industrial policymakers. From a theoretical point of view, the existence of BMlpd implies the further investigation of the interactions among them. So considered all together do they still correlate positively with business model innovation performance, or do they influence counteract? This research implies for managers the consideration of a comprehensive set of key conditions whose attainment should be planned, pursued and monitored to increase performance of BMI. The fulfilment, both in coverage and in intensity, of the set of BMIpd would be beneficial for the firm.

Thus, managers are called to actively manage BMlpd, to guarantee their update, fulfilment monitoring, fulfilment planning (Figure 2).

BMlpd should be reviewed and updated, according to market and technological changes (Afuah and Tucci, 2003; Teece, 2010; Wirtz, 2019). From a different perspective BMI drivers reflect "those management's hypothesis about what customers want, how they want it, and how the enterprise can organize to best meet those needs" (Teece, 2010) (p. 172), and reflect the hypothesis about the interactions the new BM will have with that of competitors (Casadesus-Masanell and Ricart, 2011)

A further point is that of Digital Enterprise, a theoretically and practically consistent context of observation and theory building for this challenge. They operate in markets characterized by fast changes, digital-based services, rapid technology innovation; thus, they are pressured to innovate BMs at higher market and financial performance to stay competitive (Ascent Journey 2020 Editorial Board, 2019; Kraus et al., 2019b; Zott and Amit, 2017). Most of the literature sources emerged by the research are grounded in this context, making of it a racy investigation and experimentation arena.

The identification of external BMlpd is a way to identify industry-specific drivers, to support the dynamics of BMl of Digital enterprises. Latifi and Bouwman (2018), indeed, by analysing the 
relation between $\mathrm{BMI}$ and firm's performance, identify four moderators of BMI performance on firm's performance. They regulate the influence of BMl performance on firm's performance, and can be considered as drivers of BMI, and are, namely, BMI-Implementation, BMI-Practices, Firm-characteristics, Industry-characteristics.

\section{Conclusions}

From a theoretical point of view, the Business Model Innovation performance driver defines and identifies a variable of BMI performance, from a practical perspective it provides a comprehensive set of key conditions whose attainment should be planned, pursued and monitored by managers. This research, using an integrative literature review methodology, collected the BMI performance drivers, and assessed their improvement effect on BMI performance.

The theoretical issue of BMl performance is a rising stream in research and in practice. Even more firms, and in particular Digital Enterprises, link their firm's competitiveness and sustainability with the performance of BMI. However, a clear and exhaustive frame on BMI performance is lacking. Research is lagging and BMI performance theory is far to be built (Nielsen et al., 2018). This research has shaded light on an antecedent of BMI performance, the BMl performance driver. BMl performance drivers are the conditions whose fulfilment has a positive impact on BMI performance.

We detected, by the review of existing literature, the existence of a detailed and granular correlation, between BMIpd and BMI performance.

In managerial literature, driver is generally meant as a collection of indications, suggestions, references regarding the use of resources, processes or regarding the compliance to situations and conditions, that have demonstrated to determine higher performance. Due to their general importance and to their qualitative nature, BMI drivers are often investigated in researches and proliferate in literature, but have a lacking of rigor in definition, as the concept of driver (in BMI) is rarely provided and discussed.

Some previous studies addressed the BMI drivers (Casadesus-Masanell and Ricart, 2011; Clauss, 2016; Haggège et al., 2017; Latifi and Bouwman, 2018; Zott and Amit, 2010). However, we approached the issue under a new and strategic perspective, to shed more light on the drivers for $\mathrm{BMI}$. This research, using an integrative literature review methodology, led to collect 35 BMlpds, to analyse their meaning and highlight their improvement effect on BMI performance.

Probably, the scope of this issue is wider than it appeared to our research, as the innovation of business models is an art, as much as a science, requiring other corpus of knowledge and experience of practitioners to balance the strategic and organizational challenges of optimization and experimentation (Haggège et al., 2017). Then researching BMI drivers would benefit from other disciplines and methods.

Complexity uncertainty, technology and market disruptions, in the digital competitive environment, are not approachable anymore with classic, linear theories of innovation management (product, process, service) - i.e. sequence of design and test-prototyping, forecasting of market condition as input of innovation, launch of discrete product/process development project.

Albeit the effort paid in approaching the 'fuzzy' concept of driver in BMI context, some limitations are attributable to our research: the weakness, the lability of the construct "driver" in Business Management, which has a general but not operational definition, mostly implicit in previous researches, without explicit and agreed on operative definitions, makes elusive the search of records in the literature on BMI in Digital enterprises. It has been like "fishing with bare hands", as many studies dealt with BMI drivers without explicitly use the term. This does not allowed getting results from internet search engines. 
Future research developments of this research would involve the interactions among the BMlps. In other words, how they interact each other and how they reinforce or balance.

\section{References}

Abdelkafi, N., Makhotin, S. and Posselt, T. (2013), "Business model innovations for electric mobility - what can be learned from existing business model patterns?", International Journal of Innovation Management, Vol. 17 No. 1, pp. 1-41.

Afuah, A. and Tucci, C.L. (2003), Internet Business Models and Strategies - Text and Cases, 2nd ed., McGraw Hills, New York, NY.

Amit, R. and Zott, C. (2001), "Value creation in E-business", Strategic Management Journal, Vol. 22 Nos 6/7, pp. 493-520.

Amit, R. and Zott, C. (2012), "Creating value through business model innovation", MIT Sloan Management Review, Vol. 53 No. 3, pp. 41-49.

Ammirato, S., Sofo, F., Felicetti, A.M., Helander, N. and Aramo-Immonen, H. (2020), "A new typology to characterize Italian digital entrepreneurs", International Journal of Entrepreneurial Behavior and Research, Vol. 26 No. 2, pp. 224-245.

Ascent Journey 2020 Editorial Board (2019), "Journey 2020 - digital shockwaves in business", available at: https://atos.net/content/dam/global/flipbooks/journey-2020/mobile/index.html\#p=20 (accessed 5 September 2019).

Bocken, N.M.P., Lüdeke-Freund, F. and Gold, S. (2018), "A review and typology of circular economy business model patterns", Journal of Industrial Ecology, Vol. 23 No. 1, pp. 36-61.

Bryman, A. and Bell, E. (2011), Business Research Methods, 3rd ed., Oxford University Press.

Bucherer, E. and Uckelmann, D. (2011), "Business models for the internet of things", in Uckelmann, D., Harrison, M. and Michahelles, F. (Eds), Architecting the Internet of Things, Springer, Berlin, Heidelberg.

Casadesus-Masanell, R. and Ricart, J.E. (2011), "How to design a winning business model", Harvard Business Review, Vol. 89 Nos 1/2, pp. 100-107.

Chesbrough, H. (2010), "Business model innovation: opportunities and barriers", Long Range Planning, Vol. 43 Nos 2/3, pp. 354-363.

Chesbrough, H. and Rosenbloom, R.S. (2002), "The role of the business model in capturing value from innovation: evidence from Xerox corporation's technology spin-off companies", Industrial and Corporate Change, Vol. 11 No. 3, pp. 529-555.

Christensen, C.M., Bartman, T. and Bever, D.V. (2016), "The hard truth about business model innovation", MIT Sloan Management Review, Vol. 58 No. 1, pp. 31-40.

Clauss, T. (2016), "Measuring business model innovation: conceptualization, scale development, and proof of performance", R and D Management, Vol. 47 No. 3, pp. 385-403.

Demil, B. and Lecocq, X. (2010), "Business model evolution: in search of dynamic consistency", Long Range Planning, Vol. 43 Nos 2/3, pp. 227-246.

Desyllas, P. and Sako, M. (2013), "Profiting from business model innovation: evidence from pay-as-youdrive auto insurance", Research Policy, Vol. 42 No. 1, pp. 101-116.

Dubosson, M., Osterwalder, A. and Pigneur, Y. (2002), "E-business model design, classification, and measurements", Thunderbird International Business Review, Vol. 44 No. 1, pp. 5-23.

Fisher, E. and Reuber, A.R. (2011), "Social interaction via new social media: (how) can interactions on Twitter affect effectual thinking and behavior?", Journal of Business Venturing, Vol. 26 No. 1, pp. 1-18.

Foss, N.J. and Saebi, T. (2018), "Business models and business model innovation: between wicked and paradigmatic problems", Long Range Planning, Vol. 51 No. 1, pp. 9-21.

Frankenberger, K., Weiblen, T., Csik, M. and Gassmann, O. (2013), "The 4l-framework of business model innovation: a structured view on process phases and challenges", International Journal of Product Development, Vol. 18 Nos 3/4, pp. 249-273.

Geissdoerfer, M., Savaget, P. and Evans, S. (2017), "The Cambridge business model innovation process", Procedia Manufacturing, Vol. 8, pp. 262-269. 
Geissdoerfer, M., Vladimirova, D. and Evans, S. (2018), "Sustainable business model innovation: a review", Journal of Cleaner Production, Vol. 198, pp. 401-416.

Giones, F. and Brem, A. (2017), "Digital technology entrepreneurship: a definition and research agenda", Technology Innovation Management Review, Vol. 7 No. 5, pp. 44-51.

Haggège, M., Gauthier, C. and Rüling, C.-C. (2017), "Business model performance: five key drivers", Journal of Business Strategy, Vol. 38 No. 2, pp. 6-15.

Hagiu, A. and Wright, J. (2015), "Multi-sided platforms", International Journal of Industrial Organization, Vol. 43, pp. 162-174.

Hartmann, P.M., Zaki, M., Feldmann, N. and Neely, A. (2016), "Capturing value from big data - a taxonomy of data-driven business models used by start-up firms", International Journal of Operations and Production Management, Vol. 36 No. 10, pp. 1382-1406.

Hayes, A. (2020), "What is a driver?", Investopedia, available at: www.investopedia.com (accessed 26 November 2020).

IBM Institute for Business Value (2008), "Paths to success: three ways to innovate your business model", available at: www-935.ibm.com/services/us/index.wss/ibvstudy/gbs/a1028552?cntxt=a1005266

Johnson, M.W., Christensen, C.C. and Kagermann, H. (2008), "Reinventing your business model", Harvard Business Review, Vol. 87 No. 12, pp. 52-60.

Kim, S.K. and Min, S. (2015), "Business model innovation performance: when does adding a new business model benefit an incumbent?", Strategic Entrepreneurship Journal, Vol. 9 No. 1, pp. 34-57.

Kraus, S., Palmer, C., Kailer, N., Kallinger, F.L. and Spitzer, J. (2019a), "Digital entrepreneurship: a research agenda on new business models for the twenty-first century", International Journal of Entrepreneurial Behavior and Research, Vol. 25 No. 2, pp. 353-375.

Kraus, S., Roig-Tierno, N. and Bouncken, R.B. (2019b), "Digital innovation and venturing: an introduction into the digitalization of entrepreneurship", Review of Managerial Science, Vol. 13 No. 3, pp. 519-528.

Lambert, S.C. and Davidson, R.A. (2013), "Applications of the business model in studies of enterprise success, innovation and classification: an analysis of empirical research from 1996 to 2010", European Management Journal, Vol. 31 No. 6, pp. 668-681.

Latifi, M.-A. and Bouwman, H. (2018), "Business model innovation and firm performance: the role of mediation and moderation factors", 31th Bled EConference Digital Transformation - Meeting the Challenges, University of Maribor Press, Maribor, Slovenia.

Lozano, R. (2015), "A Holistic perspective on corporate sustainability drivers", Corporate Social Responsibility and Environmental Management, Vol. 22 No. 1, pp. 32-44.

Magretta, J. (2002), "Why business models matter", Harvard Business Review, Vol. 80 No. 5, pp. 86-92.

Massa, L., Tucci, C.L. and Afuah, A. (2017), "A critical assessment of business model research", Academy of Management Annals, Vol. 11 No. 1, pp. 73-104.

Nambisan, S. (2017), "Digital entrepreneurship: toward a digital technology perspective of entrepreneurship", Entrepreneurship Theory and Practice, Vol. 41 No. 6, pp. 1029-1055.

Nielsen, C., Lund, M. and Bukh, P.N. (2014), "Moving towards maturity in business model definitions", in Nielsen, C. and Lund, M. (Eds), The Basics of Business Models, Ventus Publishing.

Nielsen, C., Lund, M., Thomsen, P.P., Kristiansen, K.B., Sort, J.C., Byrge, C., Roslender, R., Schaper, S., Montemari, M., Delmar, A.C.P. and Simoni, L. (2018), "Depicting a performative research agenda: the 4th stage of business model research", Journal of Business Models, Vol. 6 No. 2, pp. 59-64.

Osterwalder, A. and Pigneur, Y. (2010), Business Model Generation: A Handbook for Visionaries, Game Changers, and Challengers, John Wiley and Sons.

Osterwalder, A., Pigneur, I. and Tucci, C.L. (2005), "Clarifying business models: origins, present, and future of the concept", Communications of the Association for Information Systems, Vol. 16, pp. 1-25.

Pucihar, A., Lenart, G., Kljajić Borštnar, M., Vidmar, D. and Marolt, M. (2019), "Drivers and outcomes of business model innovation - micro, small and medium-sized enterprises perspective", Sustainability, Vol. 11 No. 2, pp. 344-361.

Rachinger, M., Rauter, R., Müller, C., Vorraber, W. and Schirgi, E. (2019), "Digitalization and its influence on business model innovation", Journal of Manufacturing Technology Management, Vol. 30 No. 8, pp. 1143-1160. 
Rauter, R., Jonker, J. and Baumgartner, R.J. (2017), "Going one's own way: drivers in developing business models for sustainability", Journal of Cleaner Production, Vol. 140 No. 1, pp. 144-154.

Rippa, P. and Secundo, G. (2018), "Digital academic entrepreneurship: the potential of digital technologies on academic entrepreneurship", Technological Forecasting and Social Change, Vol. 146, pp. 900-911.

Shafer, S.M., Smith, H.J. and Linder, J.C. (2005), "The power of business models", Business Horizons, Vol. 48 No. 3, pp. 199-207.

Snyder, H. (2019), "Literature review as a research methodology: an overview and guidelines", Journal of Business Research, Vol. 104 No. November 2019, pp. 333-339.

Sosna, M., Trevinyo-Rodríguez, R.N. and Velamuri, S.R. (2010), "Business model innovation through trialand-error learning: the Naturhouse case”, Long Range Planning, Vol. 43 Nos 2/3, pp. 383-407.

Spieth, P. and Schneider, S. (2016), "Business model innovativeness: designing a formative measure for business model innovation", Journal of Business Economics, Vol. 86 No. 6, pp. 671-696.

Spieth, P., Schneckenberg, D. and Ricart, J.E. (2014), "Business model innovation -state of the art and future challenges for the field", R and D Management, Vol. 44 No. 3, pp. 237-247.

Study.com (2017), "Key drivers: definition and analysis", available at: study.com/academy/lesson/keydrivers-definition-analysis.html\%0A\%0A (accessed 30 November 2020).

Techopedia (2014), "Business driver", available at: www.techopedia.com/definition/28013/businessdriver (accessed 26 November 2020).

Teece, D.J. (2010), "Business models, business strategy and innovation", Long Range Planning, Vol. 43 Nos 2/3, pp. 172-194.

Timmers, P. (1998), "Business models for electronic markets", Electronic Markets, Vol. 8 No. 2, pp. 3-8.

Torraco, R.J. (2005), "Writing integrative literature reviews: guidelines and examples", Human Resource Development Review, Vol. 4 No. 3, pp. 356-367.

Velamuri, V.K., Bansemir, B., Neyer, A.-K. and Möslein, K.M. (2013), "Product service systems as a driver for business model innovation: lessons learned from the manufacturing industry", International Journal of Innovation Management, Vol. 17 No. 1, pp. 1-25.

Wirtz, B.W. (2019), Digital Business Models, Springer Nature Switzerland.

Wirtz, B.W. and Daiser, P. (2018), "Business model development: a customer-oriented perspective", Journal of Business Models, Vol. 6 No. 3, pp. 24-44.

Zaheer, H., Breyer, Y. and Dumay, J. (2019), "Digital entrepreneurship: an interdisciplinary structured literature review and research agenda", Technological Forecasting and Social Change, Vol. 148, pp. 1-20.

Zott, C. and Amit, R. (2007), "Business model design and the performance of entrepreneurial firms", Organization Science, Vol. 18 No. 2, pp. 181-199.

Zott, C. and Amit, R. (2010), "Business model design: an activity system perspective", Long Range Planning, Vol. 43 Nos 2/3, pp. 216-226.

Zott, C. and Amit, R. (2017), "Business model innovation: how to create value in a digital world", NIM Marketing Intelligence Review, Vol. 9 No. 1, pp. 19-23.

Zott, C., Amit, R. and Massa, L. (2011), "The business model: recent developments and future research", Journal of Management, Vol. 37 No. 4, pp. 1019-1042.

\section{Corresponding author}

Roberto Linzalone can be contacted at: roberto.linzalone@unical.it

For instructions on how to order reprints of this article, please visit our website: www.emeraldgrouppublishing.com/licensing/reprints.htm

Or contact us for further details: permissions@emeraldinsight.com 